\title{
Transitory postural vasomotor dysfunction in the finger after short term hand vibration
}

\author{
N OLSEN, O U PETRING, N ROSSING \\ From the Department of Clinical Physiology and Nuclear Medicine, Rigshospitalet, University of Copenhagen, \\ Copenhagen, Denmark
}

ABSTRACT The transitory effects of hand vibration $\left(a_{\mathrm{h}, \mathrm{w}}=3.16 \mathrm{~m} / \mathrm{s}^{2}\right.$ during three minutes) on postural vasomotor functions of skin capillary blood flow rate in the finger were studied by the local ${ }^{133}$ xenon washout technique in ten men with vibration induced white finger (VWF), nine men professionally exposed to hand-arm vibration but without finger symptoms (HAV), and eight male controls (MC). The following postural vasomotor functions were measured: $(a)$ the vasomuscular, non-neurogenic autoregulation, tested by raising the finger $20 \mathrm{~cm}$; (b) the local venoarteriolar vasoconstrictor axon reflex, tested by lowering the finger $40 \mathrm{~cm}$; and $(c)$ the central sympathetic vasoconstrictor reflex elicited by central baroreceptors and tested by changing the body posture from supine to sitting upright. Before short term vibration the vasoconstriction elicited by central baroreceptors was increased in VWF $(p<0.01)$ and normal in HAV $(p>0.10)$. The local axon reflex and the autoregulation functioned normally in VWF and HAV ( $p>0.30)$. Three minutes after vibration, autoregulation was abolished and the functions of the central and local sympathetic vasoconstrictor reflexes were equally impaired in all three groups $(p \leqslant 0.01)$. All three vasomotor functions were completely restored 60 minutes after vibration in $\mathrm{MC}(\mathrm{p}>0 \cdot 10)$ and also 30 minutes after vibration in one male control $(p>0.20)$. The results indicate a hyperreactivity of the central sympathetic nervous system in VWF, and a transitory, impaired function of digital arterioles after short term vibration in all groups.

Raynaud's phenomenon, peripheral neuropathy, muscular fatigue, and enlarged fingers are all known complications of long term exposure to hand-arm vibration but the immediate effects of vibration are poorly recognised. ${ }^{1-4}$ The haemodynamic effect in the finger during short term vibration has been shown to be a vasoconstriction mediated through a vibration elicited central sympathetic reflex. ${ }^{5}$ Effects in the finger after cessation of vibration have not been reported.

The aim of the present study was to assess the immediate results of hand vibration on postural vasomotor functions of the finger. An impact drill of low vibration level widely used in private homes was used as the source of vibration and the following postural vasomotor functions were measured before and after a short term exposure to hand vibration in men with vibration induced white finger (VWF), men professionally exposed to hand-arm vibration but without finger symptoms (HAV), and age matched male controls (MC): (a) the vasomuscular, nonneurogenic autoregulation, tested by raising the finger

Accepted 19 September 1988
$20 \mathrm{~cm}^{6} ;(b)$ the local venoarteriolar vasoconstrictor axon reflex, tested by lowering the finger $40 \mathrm{~cm}^{78}$; and (c) the central sympathetic vasoconstrictor reflex elicited by central baroreceptors' and tested by changing the body posture from supine to sitting upright. ${ }^{10}$ The vasomotor responses to all three postural manoeuvres were judged by the relative change in skin capillary blood flow rate of the finger determined by local ${ }^{133}$ xenon washout technique."

\section{Subjects and methods}

The study groups included ten men with a history of VWF, nine with HAV, and eight MC. All were otherwise healthy. They gave informed consent to the study, which was approved by the local ethical committee. The three groups were matched according to age and smoking habits (table 1). The VWF and HAV groups were also matched according to the exposure period of hand-arm vibration. VWF was diagnosed and staged according to Taylor and Pelmear': stage 1, blanching of one or more fingertips; stage 2, blanching of one or more fingers; stage 3, extensive blanching of 
Table 1 Data for the three investigated groups of men

\begin{tabular}{|c|c|c|c|c|c|c|}
\hline \multirow{3}{*}{$\begin{array}{l}\text { Age (y) } \\
\text { No of smokers } \\
\text { Tobacco/day (g) } \\
\text { Duration of exposure to vibration (y) } \\
\text { Stage of VWF } \\
\text { Duration of VWF (y) } \\
\text { Latent period of VWF (y) } \\
\text { Mean arterial blood pressure (mm } \mathrm{Hg}) \\
\text { Systolic pressure gradient from upper arm to } \\
\text { finger (mm } \mathrm{Hg}) \\
\text { Finger systolic pressure at } 30^{\circ} \mathrm{C}(\mathrm{mm} \mathrm{Hg}) \\
\text { FSP\% (15\%) } \\
\text { FSP\% }\left(10^{\circ} \mathrm{C}\right)\end{array}$} & \multicolumn{2}{|c|}{$M C(n=8)$} & \multicolumn{2}{|c|}{$H A V(n=9)$} & \multicolumn{2}{|c|}{$V W F(n=10)$} \\
\hline & $\begin{array}{r}41 \\
6 \\
16\end{array}$ & $\begin{array}{r}(32-45) \\
(5-25)\end{array}$ & $\begin{array}{r}37 \\
6 \\
16 \\
16\end{array}$ & $\begin{array}{l}(29-43) \\
(5-40) \\
(9-19)\end{array}$ & $\begin{array}{r}41 \\
5 \\
20 \\
16 \\
2 \\
10 \\
8 \\
99\end{array}$ & $\begin{array}{r}(30-49) \\
(10-25) \\
(12-19) \\
(1-3) \\
(5-21) \\
(2-10) \\
(84-107)\end{array}$ \\
\hline & $\begin{array}{r}10 \\
120 \\
90 \\
85\end{array}$ & $\begin{array}{c}(-10 \text { to } 25) \\
(110-140) \\
(81-100) \\
(72-88)\end{array}$ & $\begin{array}{r}5 \\
110 \\
91 \\
78\end{array}$ & $\begin{array}{c}(0-20) \\
(100-135) \\
(60-100) \\
(20-96)\end{array}$ & $\begin{array}{r}5 \\
110 \\
67 \\
30\end{array}$ & $\begin{array}{c}(0-20) \\
(100-140) \\
(0-87)^{* \dagger}+ \\
(0-75) * \dagger\end{array}$ \\
\hline
\end{tabular}

Values are numbers or medians (ranges in parentheses). VWF = Vibration induced white finger, HAV = men professionally exposed t $\$$ hand-arm vibration but without finger symptoms, MC $=$ male controls, FSP\% $\left(15 / 10^{\circ} \mathrm{C}\right)=$ finger systolic blood pressure at finge temperature of $15^{\circ}$ or $10^{\circ} \mathrm{C}$ in percentage of finger systolic pressure at $30^{\circ} \mathrm{C}$. Stage of VWF refers to the Taylor-Pelmear scale evaluating severity of the disorder. Significant difference from corresponding value of $\mathrm{MC}$ and of $\mathrm{HAV}$, respectively: ${ }^{*} \mathrm{p}<0.01 ;$ tp $<0.02$.

most fingers with frequent episodes in summer and winter; stage 4, extensive blanching of all fingers in summer and winter leading to change of occupation.

All subjects abstained from tobacco, alcohol, and work with vibrating tools for at least three hours before the study. They were studied at a room temperature of $24.0 \pm 0.5^{\circ} \mathrm{C}$ after at least 45 minutes rest and when feeling comfortably warm without sweating. None had ischaemic or atrophic fingers. The most severely affected fingers were tested in VWF. The corresponding fingers (second to fourth) were tested in MC and HAV. Blood pressure was measured on the upper arm by auscultation method, using a $12 \mathrm{~cm}$ broad cuff. Mean arterial blood pressure was calculated as diastolic pressure plus one third of the pulse pressure (table 1). Finger systolic blood pressure was measured using strain gauge plethysmography. ${ }^{12}$ The systolic pressure gradient from upper arm to finger of VWF and HAV was within the corresponding range of MC (table 1). It was therefore assumed that none of the vibration exposed subjects had significant obstructions in the arteries leading to and through the fingers ${ }^{13}$ and that the disorder of the VWF group was a clear vasospastic disease. On a different day the vasoconstrictor response to cold was measured in the finger using a cuff and strain gauge technique. ${ }^{14}$ The finger systolic blood pressure was measured during combined body and finger cooling to $30^{\circ}, 15^{\circ}$, and $10^{\circ} \mathrm{C}$. An attack of Raynaud's phenomenon was detected as an indirectly recorded zero presure at $15^{\circ}$, or $10^{\circ} \mathrm{C}$. Findings of the cold provocation test confirmed that VWF had an exaggerated vasoconstrictor response to cold compared with those of $\mathrm{HAV}$ and MC, and that no subjects of the HAV group showed subclinical Raynaud's phenomenon (table 1).

Postural vasomotor functions of the finger were estimated from the relative change in skin capillary blood flow rate, using the difference in washout rate of a cutaneous ${ }^{133}$ xenon depot before, during, and afte宅 each postural manoeuvre. The site of radioactive skick labelling was the dorsum of the distal interphalangead joint, where there are no arteriovenous anastomoses. $\stackrel{\text {. }}{\rightarrow}$ A skin area of $12 \mathrm{~mm}$ diameter was labelled over two minutes by means of a modified atraumatic labelling technique, ${ }^{16}$ using a bowl containing $0.35 \mathrm{ml}{ }^{133}$ xenow in isotonic saline solution $(80 \mathrm{MBq})$. The disappear= ance of radioactivity from the labelled area from one minute after labelling was monitored externally wi $\mathrm{NaI}(\mathrm{Tl})$ scintillation detector with the crystal surfae 8 $\mathrm{cm}$ above the skin and wide collimation. The disâjps pearance curve, corrected for background activity was plotted against time in a semilogarithmic scale.

The reference body posture in all three postural test was with the subject lying supine with the finger at the: midaxillary line. Autoregulation was investigated by raising the finger $20 \mathrm{~cm}^{6}$. The washout rate of one depot was measured $(a)$ during reference body pose ture, $(b)$ when the finger was raised $20 \mathrm{~cm}$, and $(c)$ in the reference body posture. Each period of measurement lasted for about two minutes. The local venoarteriolar? axon reflex was investigated by lowering the finger 49 $\mathrm{cm}^{68}$ The central sympathetic vasoconstrictor reflex. elicited by the central baroreceptors, ${ }^{9}$ was investigate with the subject sitting on a chair with a straight back and with the finger kept at the level of the jugulap notch. ${ }^{10}$ Pulse rate and arm blood pressure was measured on the contralateral arm during each period. of the sitting test. Each postural test was performegy after repeated labelling.

Subsequently, the subjects were exposed to unilateral hand vibration of 165 seconds duration by using an impact drill (Bosch SB 350E) kept with minimal pressure on a flint stone embedded in $\Phi$ concrete block. Typical root-mean-square accelera tion spectra of the handle of the used impact drill measured in the direction of the $\mathrm{Z}$ axis ${ }^{17}$ are shown in 
fig 1 . The acceleration level and its reproducibility were calculated from repeated measurements of three operators according to the guidelines of the International Organisation for Standardisation. ${ }^{17}$ Ten measurements were performed for each operator. The median acceleration level and its total ranges were $L_{h \text {, w }}$ $=130.0 \mathrm{~dB}(129.8-130.4)$ with no significant difference between the three operators $(p>0.95)$. Expressed in $\mathrm{m} / \mathrm{s}^{2}$ the median acceleration was $3 \cdot 16\left(\mathrm{a}_{\mathrm{h}, \mathrm{w}}\right)$. This vibration should induce VWF after four hours daily exposure during ten years in about $11 \%$ of such exposed subjects. ${ }^{17}$

Fifteen seconds after vibration exposure ended, the finger was labelled, and three minutes later, measurement of the first reference period of the sitting test was made. The contralateral hand was then exposed to vibration followed by measurements of the relative blood flow rate when the finger was raised 20 $\mathrm{cm}$. The hand first vibrated was then re-exposed after at least one hour followed by measurements on the ipsilateral finger when the finger was lowered $40 \mathrm{~cm}$. Thus all three postural tests were repeated 195 seconds after the end of vibration in all subjects. The MC group was further tested 60 minutes after the end of vibration; one male control was also tested 30 minutes after vibration ceased.

The five months variation coefficient of relative blood flow rate in the sitting test was calculated from double determinations of the HAV group. The haemodynamic response to sitting and to lowering the finger $40 \mathrm{~cm}$ was also measured before vibration during conventional nerve block of the finger in eight of the HAV group and in eight of the VWF group. Blockade was performed by applying $4 \mathrm{ml} 2 \%$ lido-

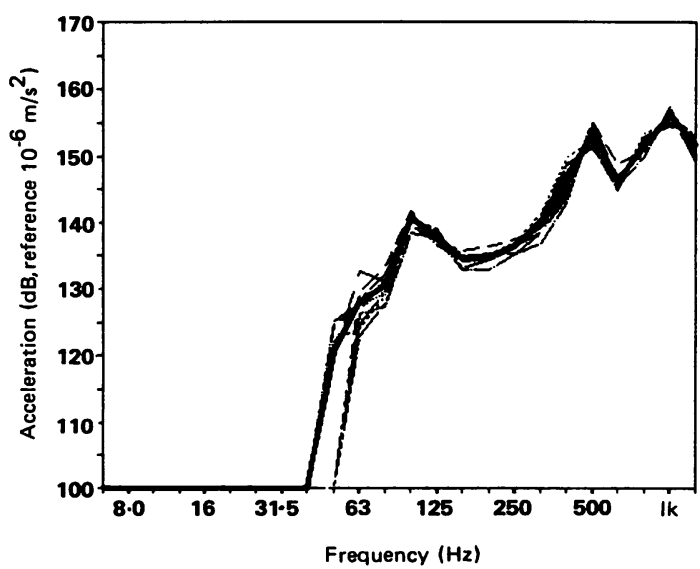

Fig 1 Reproducibility of vibration spectrum for handle of used impact drill. Thin curve lines represent ten repeated recordings obtained from one operator. Thick curve line represents their mean value. caine at the base of the finger and was considered to be effective when perception was lost to pinprick and temperature. These ${ }^{133}$ xenon measurements started once the finger systolic pressure had returned to normal. The measurements of the postural test, where the finger was raised $20 \mathrm{~cm}$, were repeated before vibration in ten men (4 MC, $2 \mathrm{HAV}$, and $4 \mathrm{VWF}$ subjects) three minutes after a firm hand grip during 165 seconds around the handle of the non-running impact drill to assess the possible effect of hand grip on the function of autoregulation.

\section{CALCULATIONS AND STATISTICS}

The washout rate constant $\left(\mathrm{min}^{-1}\right)$ in all three postural tests was defined as $(a)$ the slope of the radioactivity disappearance curve $\left(k_{1}\right)$ in the first reference period before the postural stimulus, $(b)$ the slope $\left(\mathbf{k}_{2}\right)$ in the test period, and $(c)$ the steepest slope $\left(\mathbf{k}_{3}\right)$ in the second reference period after the postural stimulus. ${ }^{10}$ The rate constants were computed from the regression line calculated from the least square method. The relative blood flow rate (F) of each postural test was defined as the numerical value of $k_{2} /\left(0 \cdot 5 \cdot\left(k_{1}+k_{3}\right)\right) \cdot{ }^{810}$ Examples of ${ }^{133}$ xenon washout curves have been published. ${ }^{10}$ The degree of impairment of the autoregulation three minutes after vibration was calculated as follows: 100 . $\left(F_{1}-F_{2}\right) /\left(1-F_{c}\right)(\%) ; F_{c}=(M A B P-15 \cdot 7) / M A B P$, where $F_{1}$ denotes relative blood flow rate $(F)$ before vibration, $F_{2}$ denotes $F$ after vibration, $F_{c}$ denotes the estimated $\mathbf{F}$ at completely abolished autoregulation, MABP denotes mean arterial blood pressure when lying supine with the finger at the midaxillary line, and 15.7 is the estimated hydrostatic pressure in $\mathrm{mm} \mathrm{Hg}$ of $20 \mathrm{~cm}$ whole blood. With the finger lowered $40 \mathrm{~cm}$ and with the finger at the jugular notch when sitting the degree of impairment of these two vasomotor functions was calculated as: $100\left(F_{2}-F_{1}\right) /\left(1-F_{1}\right)(\%)$, where $F_{1}$ and $F_{2}$ denotes relative blood flow rate of the respective tests before and three minutes after vibration. Change in mean arterial blood pressure and pulse rate from lying to sitting upright was calculated as the difference between the value of sitting and the average value of lying measured before and after the period of sitting. The numerical mean value of the washout rate constants of the first reference period was calculated from the three postural tests before and three minutes after vibration, respectively.

The difference in nominal values between independent groups of subjects was tested with the chi-squared test for $\mathbf{k}$ independent samples. The difference in numerical values between independent groups was tested with the Kruskal-Wallis one way analysis of variance, followed by the Mann-Whitney rank sum test if the Kruskal-Wallis test showed significant differences. The difference in numerical values between related samples was tested with the Friedman 
two way analysis of variance if more than two samples followed by the Wilcoxon matched pairs signed ranks test if the Friedman test showed significant differences. In the single male control, who was also tested 30 minutes after vibration, the standard deviation (SD) of a $F$ value was calculated from the standard deviations of the washout rate constants-that is, $\operatorname{SD}\left(k_{1}\right), \operatorname{SD}\left(k_{2}\right)$, $\mathrm{SD}\left(\mathrm{k}_{3}\right)$ - using the formula:

$$
\begin{aligned}
& \mathrm{SD}(\mathrm{F})= \\
& \mathrm{F} \cdot \sqrt{\left.\left(\mathrm{SD}^{2}\left(\mathrm{k}_{2}\right) / \mathbf{k}_{2}^{2}\right)+\frac{\left[\left(\mathrm{SD}^{2}\left(\mathbf{k}_{1}\right)\right.\right.}{\left.\left(\left(\mathrm{k}_{1}+\mathbf{k}_{3}\right)^{2}\right)\right]}+\mathrm{SD}^{2} \quad\left(\mathrm{k}_{3}\right)\right) /}
\end{aligned}
$$

The difference between two $F$ values of this subject was then tested against the null hypothesis. A significance limit of 0.05 (two tailed) was used in all statistical tests. Results are given as medians and ranges or as $F$ values and 1 SD unless stated otherwise.

The variation coefficient of the sitting test was calculated as $S_{\text {diff }}$ in percentage of mean $F$ value of the first determination where $\mathrm{SD}_{\text {dif }}=\sqrt{\mathrm{d}^{2} / 2 \mathrm{n}} ; \mathrm{d}$ is the difference between two repeated measurements and $n$ is number of duplicates.

\section{Results}

There was no change in mean arterial blood pressure from lying supine to sitting upright in the total group of subjects $(p>0 \cdot 10, n=27)$ before vibration and there were no significant differences between the three groups $(p>0 \cdot 10)$. There was, however, a significant increase in pulse rate of $5 \mathrm{~min}^{-1}(0-14)(\mathrm{p}<0.01, \mathrm{n}=$ 27) with no significant difference between the three groups $(\mathrm{p}<0 \cdot 10)$. This was unchanged three minutes after vibration. Table 2 gives the five months variation coefficient of the sitting test and other methodological results.

Table 3 shows the relative blood flow rates of the finger during postural manoeuvres before and after hand vibration in the three groups. Before vibration the vasoconstriction to sitting was increased in $\mathrm{VWF}_{\bar{z}}$ when compared with those of the HAV and $M C^{\circ}$ groups ( $p<0.01)$ whereas the HAV and MC groups showed the same degree of vasoconstriction $(p>$ ? $0 \cdot 10)$. The relative blood flow rates before vibration did not differ significantly between the three groups when the finger was lowered $40 \mathrm{~cm}$ and when the finger? was raised $20 \mathrm{~cm}(\mathrm{p}>0.30)$. Three minutes after $\overline{\bar{c}}$ vibration the vasoconstriction to sitting and to lowering the finger $40 \mathrm{~cm}$ decreased in all three groups $(p \leqslant \varrho$ $0.01)$. The $F$ value three minutes after vibration of ${ }^{0}$ raising the finger $20 \mathrm{~cm}$ was equally decreased in all $\vec{\circ}$ groups $(p \leqslant 0.01)$. Sixty minutes after vibration the $F_{-}^{-}$ values of all three postural tests of the MC group $\operatorname{did}_{\omega}$ not differ from those measured before vibration $(p>\rho$ $0 \cdot 10)$. The degree of impairment of the three postural@ vasomotor functions three minutes after vibration did $\$$ not differ between the three groups $(p>0 \cdot 10)$. In totalo ( $n=27$ ) its median was $107 \%$ with the finger raised 2000 $\mathrm{cm}, 39 \%$ with the finger lowered $40 \mathrm{~cm}$, and $54 \%$ when $Y$ sitting upright, without significant difference between $\mathrm{O}$ the two last mentioned values $(p>0 \cdot 10)$.

Figure 2 shows the results of the single male control, who was also tested 30 minutes after vibration. The vasomotor functions of the three postural tests were $\frac{c}{\omega n}$ significantly impaired three minutes after vibration $\left(\mathrm{p}_{-}\right.$ $\leqslant 0.0004$ ) and completely restored 30 and 60 minutese after vibration $(p>0.20)$.

The median value of the calculated washout constant of the first reference period was in total (n 27) $0.365 \mathrm{~min}^{-1}$ before vibration and $0.309 \mathrm{~min}^{-1}$ three minutes after vibration $(p<0.03)$ with no significanto difference between the three groups $(p>0 \cdot 10)$.

\section{Discussion}

METHODOLOGICAL ASPECTS

Using the present techniques, the vasomuscular autoregulation and the local venoarteriolar reflex were.

\begin{tabular}{|c|c|c|c|}
\hline $\begin{array}{l}\text { Postural } \\
\text { manoeuvre }\end{array}$ & Situation & $\begin{array}{l}\text { Relative blood } \\
\text { flow rate }\end{array}$ & $\begin{array}{l}\text { Group of } \\
\text { men }\end{array}$ \\
\hline Sitting with finger at jugular notch & $\begin{array}{l}\text { First determination } \\
\text { Second determination } \\
\text { Variation coefficient ( } \%)\end{array}$ & $\begin{array}{l}0.78(0.71-0.91) \\
0.80(0.75-0.92 \dagger \\
5.6 \text { (five months) }\end{array}$ & HAV $(n=9)$ \\
\hline Finger lowered $40 \mathrm{~cm}$ & $\begin{array}{l}\text { Without proximal nerve block } \\
\text { During proximal nerve block }\end{array}$ & $\begin{array}{l}0.57(0.42-0.71) \\
0.60(0.49-0.75) \dagger\end{array}$ & VWF $(n=8)$ \\
\hline Sitting, finger at jugular notch & $\begin{array}{l}\text { Without proximal nerve block } \\
\text { During proximal nerve block }\end{array}$ & $\begin{array}{l}0.81(0.71-0.91) \\
1.01(0.90-1.09)^{*}\end{array}$ & HAV $(n=8)$ \\
\hline Finger raised $20 \mathrm{~cm}$ & $\begin{array}{l}\text { Before hand grip } \\
\text { Three min after hand grip }\end{array}$ & $\begin{array}{l}0.98(0.92-0.99) \\
0.99(0.92-1.08) \dagger\end{array}$ & $\begin{array}{l}\text { Ten men: } M C(n=4) \\
\operatorname{HAV}(n=2), \operatorname{VWF}(n=4)\end{array}$ \\
\hline
\end{tabular}

Table 2 Methodological results of relative blood flow rate in the finger during postural manoeuvres

Values are medians (ranges in parentheses). Reference body posture was lying supine with finger at midaxillary line. Nerve block was performed at the base of the finger. Hand grip refers to a firm grip during $165 \mathrm{~s}$ around the handle of the non-running impact drill. * Significantly different from corresponding value of same postural manoeuvre in other situation of same group of men, $p=0.01$. + Not significantly different from corresponding value of same postural manoeuvre in other situation of same group of men, $p \geqslant 0 \cdot 10$. 
Transitory postural vasomotor dysfunction in the finger after short term hand vibration

ible 3 Relative blood flow rates of the finger during postural manoeuvres before and after short term hand vibration

\begin{tabular}{|c|c|c|c|c|c|}
\hline \multirow[b]{2}{*}{$\begin{array}{l}\text { istural } \\
\text { inoeuvre }\end{array}$} & \multirow{2}{*}{$\begin{array}{l}\text { Tested } \\
\text { vasomotor } \\
\text { regulatory } \\
\text { mechanism }\end{array}$} & \multirow[b]{2}{*}{$\begin{array}{l}\text { Group of } \\
\text { men }\end{array}$} & \multicolumn{3}{|c|}{ Relative blood flow rate } \\
\hline & & & $\begin{array}{l}\text { Before } \\
\text { vibration }\end{array}$ & $\begin{array}{l}\text { Three min after } \\
\text { vibration }\end{array}$ & $\begin{array}{l}\text { Sixty min after } \\
\text { vibration }\end{array}$ \\
\hline nger raised $20 \mathrm{~cm}$ & $\begin{array}{l}\text { Arteriolar muscular } \\
\text { autoregulation }\end{array}$ & $\begin{array}{l}\operatorname{MC}(n=8) \\
\text { HAV }(n=9) \\
\text { VWF }(n=10)\end{array}$ & $\begin{array}{l}0.99(0.97-1.11) \$ \\
0.96(0.92-1.09) \$ \\
0.99(0.96-1.01)\end{array}$ & $\begin{array}{l}0.80(0.71-0.94)^{*} \\
0.80(0.67-0.90)^{*} \\
0.82(0.73-1.00)^{*}\end{array}$ & $1.00(0.96-1.06) \S$ \\
\hline nger lowered $40 \mathrm{~cm}$ & $\begin{array}{l}\text { Local venoarteriolar axon } \\
\text { reflex }\end{array}$ & $\begin{array}{l}\text { MC }(n=8) \\
\text { HAV }(n=9) \\
\text { VWF }(n=10)\end{array}$ & $\begin{array}{l}0.99(0.90-1.01) 8 \\
0.54(0.44-0.75) \\
0.59(0.40-0.69) \\
0.57(0.42-0.71)\end{array}$ & $\begin{array}{l}0.82(0.75-1.00)^{*} \\
0.69(0.59-0.99)^{*} \\
0.73(0.57-1.10)^{*} \\
0.66(0.49-1.04)\end{array}$ & $0.58(0.42-0.73)$ \\
\hline $\begin{array}{l}\text { tting with finger at } \\
\text { zular notch }\end{array}$ & $\begin{array}{l}\text { Central sympathetic } \\
\text { baroreceptor reflex }\end{array}$ & $\begin{array}{l}\operatorname{MC}(n=8) \\
\text { HAV }(n=9) \\
\text { VWF }(n=10)\end{array}$ & $\begin{array}{l}0.83(0.71-0.92) \\
0.80(0.75-0.92) \\
0.56(0.47-0.66) \dagger \ddagger\end{array}$ & $\begin{array}{l}0.95(0.85-1.10)^{*} \\
0.89(0.75-1.03)^{*} \\
0.76(0.58-0.97)^{*}+\ddagger\end{array}$ & $0.81(0.73-0.88)$ \\
\hline
\end{tabular}

tues are medians (ranges in parentheses). Reference body posture was lying supine with finger at midaxillary line.

ignificantly different from corresponding value of same postural manoeuvre before vibration in same group of men, $p \leq 0.01$.

ignificant difference from corresponding value of same postural manoeuvre at same situation in MC and $\mathrm{HAV}$, respectively: †p $<0.02 ;$; $<<0.05$. lot significantly different from unity, $p>0 \cdot 10$.
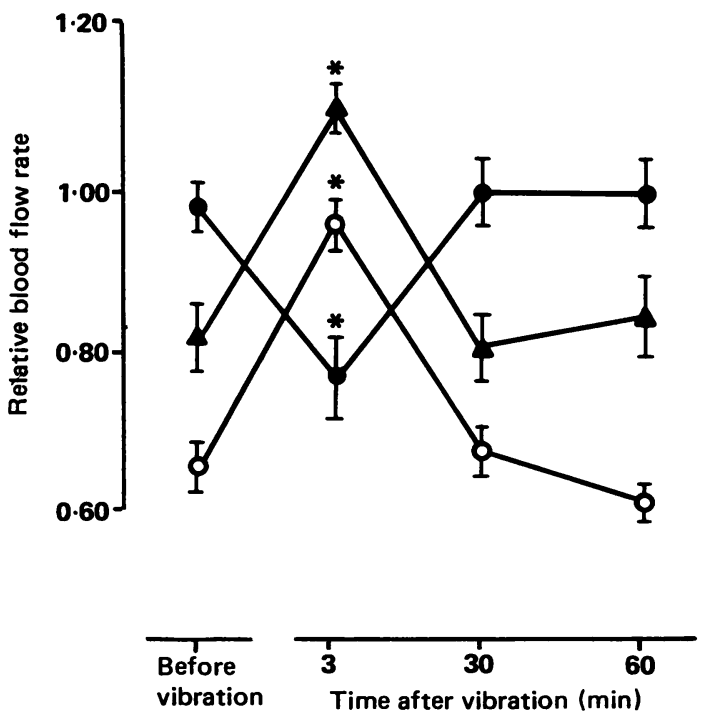

Fig 2 Relative blood flow rates of finger during postural manoeuvres before and after short term hand vibration in a male control. Reference body posture was lying supine with finger at midaxillary line. Values are relative rates $\pm 1 S D$. - Finger raised $20 \mathrm{~cm}$, $O$ finger lowered $40 \mathrm{~cm}, \Delta$ sitting upright with finger at jugular notch. *Significantly different from corresponding value of same postural manoeuvre before vibration, $p \leqslant 0.0004$.

recognised in the normal finger before vibration as in other studies. ${ }^{6}$

The vasoconstrictor response to sitting was investigated using nervous blockade at the base of the finger placed 6-7 cm proximal to the area investigated. This distance exceeds the radius of action of the local axon reflex. ${ }^{78}$ Thus vasoconstriction of the axon reflex was expected to remain unaffected if the volume of lidocaine did not significantly compress the veins draining the investigated anatomical region. In agreement with these assumptions the vasoconstriction elicited by lowering the finger $40 \mathrm{~cm}$ was unchanged during nerve block. The applied blockade seems therefore suitable in distinguishing between centrally and locally mediated sympathetic vasoconstrictor reflexes. The vasoconstriction in sitting posture was significantly abolished by nervous blockade, indicating a central sympathetic vasoconstrictor reflex in agreement with our earlier suggestion..$^{10}$ This was further supported by our results of an unchanged mean arterial blood pressure in parallel with increased pulse rate during sitting upright. The results correspond with those from earlier passive head-up tilt studies.' The sitting test was found to have an acceptable reproducibility, the five months variation coefficient being about $6 \%$.

The vasomuscular autoregulation appears to be sensitive to arterial carbon dioxide tension and oxygen saturation. ${ }^{18}$ Autoregulation, however, was intact three minutes after a three minutes firm hand grip around the handle of the non-running impact drill. Thus an impairment of autoregulation three minutes after vibration was assumed to be exclusively caused by vibration and not by ischaemia.

\section{PREVIBRATION SITUATION}

No injury of the postural vasomotor functions was detected in the HAV group. The VWF group showed a normal function of the autoregulation and the local axon reflex. Consequently, no damage to the digital arterioles or the postganglionic sympathetic nerve fibres was detected in this group. The VWF group showed an exaggerated vasoconstriction to sitting upright, verifying earlier findings. ${ }^{10}$ This result may be explained by a hyperreactivity of the central sympathetic nervous system in subjects with VWF as their postganglionic elements functioned normally. Our results seem to correspond with Raynaud's suggestion of hyperreactivity of the central sympathetic nervous 
system in subjects with vasospastic types of the phenomenon ${ }^{19}$ and contrast with the suggestion by Lewis of a "local digital vascular fault."

\section{POSTVIBRATION SITUATION}

The results obtained three minutes after vibration showed abolished autoregulation and equally impaired functions of the local and central sympathetic vasoconstrictor reflexes in all three groups. In total the impairment was about $100 \%$ for autoregulation and about $40-50 \%$ for the two neurogenic reflexes. Thus autoregulation was the most vulnerable vasomotor function injured by vibration. It has been suggested that the local axon reflex and the central sympathetic reflex might affect greater arterioles, which are richly innervated by adrenergic sympathetic nerve fibres, whereas non-neurogenic autoregulatory reactions of arteriolar smooth muscle cells take place preferentially in the terminal arterioles. ${ }^{7}$ This postulate seems verified by the findings of many young insulin-dependent patients with bioptically verified terminal arteriolar hyalinosis in the skin having disturbed or impaired autoregulation, ${ }^{21}$ but normal local and central postural reflexes. ${ }^{212}$ Our results may therefore, indicate that short term low level vibration leads to an immediate abolition of intrinsic autoregulatory function in terminal arteriolar smooth muscle cells and a net impairment of the function of postganglionic sympathetic nerve fibres and smooth muscle cells of greater arterioles. The assumption of a changed activity of the central sympathetic nervous system three minutes after vibration is therefore not needed for further explanation. It is reasonable to suppose that the musculature of larger arterioles also shows an impaired function after vibration. This would agree with results of in vitro and in vivo studies in animals, showing a vibration induced inhibition of smooth muscle contraction in veins and arteries ${ }^{23-25}$ probably caused by a direct mechanical effect on the actin myosin cross links of the vascular smooth muscle cell. ${ }^{25}$ Our results cannot evaluate whether an affection of postganglionic sympathetic nerve fibres contributes to the net impairment of the neurogenic vasomotor functions.

The current impairment of vasomotor functions was associated with a small decrease in skin capillary blood flow rate at reference body posture. This may be explained as an after effect of the vasoconstriction induced during vibration. ${ }^{5}$ Contrary to this outcome, the results obtained in anaesthetised, vibration exposed dogs show an immediate after effect of increased arterial blood flow rate in the test limb, ${ }^{26}$ apparently because anaesthesia of dogs with sodium pentobarbital ${ }^{26}$ blocks the vibration elicited central sympathetic vasoconstrictor reflex. ${ }^{5}$

Sixty minutes after vibration, all three postural vasomotor functions were completely restored in the male controls, and even after 30 minutes in the one person tested. No hyperreactivity of the functions was measured at that time, contrary to earlier resule obtained from in vitro and in vivo animal experiment showing hyperresponsiveness of arterial smooth mus? cle to adrenaline one hour after vibration ${ }^{2326}$ but if agreement with later in vitro studies. ${ }^{24}$ This discrepo ancy of results may be explained by differences in the used frequencies, levels, and periods of vibration.

We may conclude that the present vibration of los level widely experienced in private homes induces an immediate impairment of postural vasomotor functions, completely restored within 30 minutes ang without hyperreactivity 60 minutes after vibration.

\section{PATHOPHYSIOLOGICAL ASPECTS}

Our present and earlier results indicate that activatio of the vibration elicited central sympathetic vasocono strictor reflex during several years of work with vibrating hand tools may induce hyperreactivity of the central sympathetic nervous system in predisposed subjects. ${ }^{510}$ This central neurogenic hyperreactivity probably causes exaggerated digital vasoconstriction to cold and exaggerated cochlear vasoconstriction to noise, leading to Raynaud's phenomenon ${ }^{27}$ as well as ${ }^{2}$ to hearing loss ${ }^{28}$ Episodes of Raynaud's phenomenon never or only rarely occur immediately after exposgrę to vibration but are displayed typically in the morning before work and in leisure periods. ${ }^{1}$ This characterightie pattern of attacks of VWF may be caused by the demonstrated impairment of postganglionic elements immediately after exposure to vibration.

Repeated transitory impairment of the posturaf central sympathetic vasoconstrictor reflex, which cone tributes to the maintenance of systemic blood pressure by increasing the peripheral resistance to blood flow during erected body posture, ${ }^{9}$ may contribute to the. development of autonomic disorders such as the dizziness and orthostatic hypotension reported in some operators of vibrating hand tools. ${ }^{29}$

The postvibration impairment of the local veno arteriolar axon reflex, which serves as a local oedemæ protecting factor, ${ }^{78}$ may cause transitory oedema in the finger similar to the vibration induced epineuras oedema observed in the sciatic nerve of rats. 39 Repeated oedema during several years of exposure to. vibration may lead to enlarged fingers, ${ }^{4}$ periphera, muscular fatigue, ${ }^{3}$ and peripheral neuropathy ${ }^{2}$ is operators with and without VWF.

This investigation was supported by the Danist Health Insurance Foundation.

Requests for reprints to: Dr N Olsen. 


\section{References}

1 Taylor W, Pelmear PL. Vibration white finger in industry. London: Academic Press, 1975:xvii-xxii.

2 Alaranta H, Seppäläinen AM. Neuropathy and the automatic analysis of electromyographic signals from vibration exposed workers. Scand J Work Environ Health 1977;3:128-34.

3 Fárkkiłá MA, Pyykkó I, Starck JP, Korhonen OS. Hand grip force and muscle fatigue in the etiology of the vibration syndrome. In: Brammer AJ, Taylor $\mathrm{W}$, eds. Vibration effects on the hand and arm in industry. New York: John Wiley, 1982:45-50.

4 Pelmear PL, Taylor W, Pearson JCG. Clinical objective tests for vibration white finger. In: Taylor W, Pelmear PL, eds. Vibration white finger in industry. London: Academic Press, 1975:53-81.

5 Olsen N, Petring OU. Vibration elicited vasoconstrictor reflex in Raynaud's phenomena. Br J Ind Med 1988;45:415-9.

6 Kristensen JK. Local regulation of blood flow in cutaneous and subcutaneous tissue in patients with generalized scleroderma. Acta Derm Venereol 1980;suppl 90:1-39. (Thesis.)

7 Henriksen 0 . Local sympathetic reflex mechanism in regulation of blood flow in human subcutaneous adipose tissue. Acta Physiol Scand 1977;suppl 450:1-48. (Thesis.)

8 Henriksen O, Sejrsen P. Local reflex in microcirculation in human cutaneous tissue. Acta Physiol Scand 1976;98:227-31.

9 Skagen K. Sympathetic refiex control of blood flow in human subcutaneous tissue during orthostatic manoeuvres. Dan Med Bull 1983;30:229-41. (Thesis.)

10 Olsen N, Petring OU, Rossing N. Exaggerated postural vasoconstrictor reflex in Raynaud's phenomenon. Br Med J 1987; 294:1186-8.

11 Sejrsen P. Blood flow in cutaneous tissue in man studied by washout of radioactive xenon. Circ Res 1969;25:215-29.

12 Hirai M, Nielsen SL, Lassen NA. Blood pressure measurement of all five fingers by strain gauge plethysmography. Scand J Clin Lab Invest 1976;36:627-32.

13 Hirai MH. Arterial insufficiency of the hand evaluated by digital blood pressure and arteriographic findings. Circulation 1978; 58:902-8.

14 Nielsen SL, Lassen NA. Measurement of digital blood pressure after local cooling. J Appl Physiol 1977;43:907-10.

15 Grant RT, Bland EF. Observations on arteriovenous anastomoses in human skin and in the bird's foot with special reference to reaction to cold. Heart 1931;15:385-411.

16 Sejrsen P. Atraumatic local labeling of skin by inert gas: epicutancous application of xenon 133. J Appl Physiol 1968;24:570-2.

17 International Organisation for Standardisation. Mechanical vibra- tion-guidelines for the measurement and the assessment of human exposure to hand-transmitted vibration. Switzerland: International Organisation for Standardisation, 1986. (International Standard ISO 5349-1986(E).)

18 Hággendall E, Johansson B. Effects of arterial carbon dioxide tension and oxygen saturation on cerebral blood flow autoregulation in dogs. Acta Physiol Scand 1965;suppl 258: 27-53.

19 Raynaud M. De l'asphyxie locale et de la gangrene symetrique des extrémités. Paris: Rignoux, 1862.

20 Lewis T. Experiments relating to peripheral mechanism involved in spasmodic arrest of the circulation in the fingers. A variety of Raynaud's disease. Heart 1929;15:7-101.

21 Kastrup J, Nørgaard T, Parving H-H, Henriksen O, Lassen NA. Impaired autoregulation of blood flow in subcutaneous tissue of long-term type 1 (insulin-dependent) diabetic patients with microangiopathy: an index of arteriolar dysfunction. Diabetologia 1985;28:711-7.

22 Kastrup J, Nørgaard T, Paving H-H, Lassen NA. Arteriolar hyalinosis does not interfere with the local veno-arteriolar reflex regulation of subcutaneous blood flow in insulin-dependent diabetic patients. Scand J Clin Lab Invest 1987;47:483-9.

23 Azuma T, Ohhashi T, Sakaguchi M. Vibration-induced hyperresponsiveness of arterial smooth muscle to noradrenaline with special reference to Raynaud's phenomenon in vibration disease. Cardiovasc Res 1978;12:758-64.

24 Lindblad LE, Lorenz RR, Shepherd JT, Vanhoutte PM. Effect of vibration on a canine cutaneous artery. Am J Physiol 1986;250:H519-23.

25 Ljung B, Sivertsson R. Vibration-induced inhibition of vascular smooth muscle contraction. Blood Vessels 1975;12:38-52.

26 Azuma T, Ohhashi T, Sakaguchi M. An approach to the pathogenesis of "white finger" induced by vibratory stimulation: acute but sustained changes in vascular responsiveness of canine hindlimb to noradrenaline. Cardiovasc Res 1980;14:725-30.

27 Olsen N, Fjeldborg P, Brøchner-Mortensen J. Sympathetic and local vasoconstrictor response to cold in vibration induced white finger. Br J Ind Med 1985; 42:272-5.

28 Pyykkö I, Starck J, Pekkarinen J. Further evidence of relation between noise-induced permanent threshold shift and vibration-induced digital vasospasms. Am J Otolaryngol 1986;4:391-8.

29 Pyykkö I. Clinical aspects of hand-arm vibration syndrome. A review. Scand J Work Environ Health 1986;12:439-47.

30 Lundborg G, Dahlin LB, Danielsen N, Hansson HA, Necking LE, Pyykkö I. Intraneural edema following exposure to vibration. Scand J Work Environ Health 1987;13:326-9. 